Article

\title{
Effects of Acute Hyperthermia on the Thermotolerance of Cow and Sheep Skin-Derived Fibroblasts
}

 \\ Hammed A. Tukur ${ }^{1}$ and Abdullah N. Alowaimer ${ }^{1}$ \\ 1 Department of Animal Production, College of Food and Agricultural Sciences, King Saud University, \\ 11451 Riyadh, Saudi Arabia; aswelum@ksu.edu.sa (A.A.-A.S.); tukurhammeda@gmail.com (H.A.T.); \\ aowaimer@ksu.edu.sa (A.N.A.) \\ 2 Department of Physiology, Faculty of Veterinary Medicine, Zagazig University, 44519 Zagazig, Egypt \\ 3 Department of Theriogenology, Faculty of Veterinary Medicine, Zagazig University, 44519 Zagazig, Egypt \\ 4 Plant Protection Department, College of Food and Agricultural Sciences, King Saud University, \\ 11451 Riyadh, Saudi Arabia; azakri@ksu.edu.sa \\ * Correspondence: isaadeldin@ksu.edu.sa; Tel.: +966-530-910-740 \\ + These authors contributed equally to this work.
}

Received: 13 January 2020; Accepted: 20 March 2020; Published: 25 March 2020

check for updates

Simple Summary: We compared the thermotolerance of cow and sheep fibroblasts after exposure to acute hyperthermia $\left(45^{\circ} \mathrm{C}\right.$ for $4 \mathrm{~h}$ ). The primary culture, first passage, and cryopreserved cow fibroblasts resisted acute hyperthermia in terms of cell viability, proliferation, and migration to close cell scratch, in addition to increased expression of heat shock protein (HSP70 and HSP90) mRNA transcripts.

\begin{abstract}
This study was conducted to compare the effects of acute hyperthermia ( $45^{\circ} \mathrm{C}$ for $4 \mathrm{~h}$ ) on the viability, proliferation, and migratory activity through wound-healing assays of cow and sheep fibroblasts. The study examined the effects on primary cultures and first passage skin-derived fibroblasts. Relative quantification of HSP70, HSP90, P53, BAX, BCL2, and BECN1 was investigated after normalization to housekeeping genes GAPDH and beta-actin. The results revealed that cultured cow primary fibroblasts exhibited increased viability and reinitiated cell migration to close the cell monolayer scratch earlier than sheep cells. Similar patterns were observed in the first passage fibroblasts, with severe effects on sheep cells. Both cow and sheep cells exhibited decreased cell viability and failed to regain migratory activity after re-exposure of recovered heat-shocked cells. Effects of hyperthermia on sheep cells were potentiated by cell cryopreservation. The qPCR results showed that cow cells significantly increased HSP70 and HSP90 expression, which decreased the elevation of P53, and ameliorated the effects of the increased BAX/BCL2 ratio. The results provide a paradigm to compare thermotolerance among different animal species and revealed that trypsin could be an additional stress, which potentiates the effects of heat shock in in vitro experiments.
\end{abstract}

Keywords: fibroblasts; hyperthermia; thermotolerance; heat shock proteins; cows; sheep

\section{Introduction}

Heat stress (HS) has major effects on milk production and fertility in cows and sheep [1-6]. Genetic variations in susceptibility to hyperthermia have been reported among different species [7]. Acclimation or adaptation to increased temperatures basically depends on physical mechanisms, such as heat dissipation through conduction, convection, radiation, and evaporation by means of sweating 
or panting [8-10]. At the cellular level, acclimation can occur as part of the cellular heat tolerance mechanisms. In cattle and sheep cells, thermotolerance is higher in breeds adapted to warm climates than in animals with temperate origins [11-14]. This resistance could be mediated by heat shock protein (HSP)-related mechanisms [15]. HSPs are a family of proteins with diverse molecular weights $(100,90,70$, and $60 \mathrm{kDa})$ and act to prevent thermal damage to proteins [16,17]. This acute response plays a pivotal role in the cellular thermal acclimation mechanism to high temperatures and could be used as a marker for the adaptation capabilities of animals to thermal stress $[8,16,18,19]$.

Among HSPs, HSP70, and HSP90 are the two major types that have the potential to bind to unfolded proteins, helping them to fold and synthesize properly [20,21]. Some types of these proteins could be expressed substantially, whereas most of them are expressed under stress conditions [22]. Several environmental or physiologic stresses could lead to the production and activation of HSPs, such as inflammation, hypoxia, chemotherapy, and infections, as well as thermal injury $[3,16,17,23,24]$. In living systems, HSPs have essential activities, including polypeptide folding, protein transportation, and multiprotein complex formation [25]. Moreover, they can prevent apoptosis, clear aggregated proteins, and ameliorate the cytotoxic impact of toxic proteins.

Thermotolerance is a phenomenon in which cells become resistant to elevated temperatures. Thermotolerance can develop rapidly after the first heat treatment or during thermal treatment at $\sim 43.0^{\circ} \mathrm{C}$. Studies have shown that thermotolerance also develops in tumors and normal tissues $[26,27]$ and is well correlated with the enhanced synthesis of heat shock proteins [27-30]. The kinetics of thermotolerance can be affected by various factors [26,31]. For instance, thermotolerance was found physiologically in certain species as a form of estivation [32,33]. It could vary among certain cells in the same species $[17,34]$. Cells show variability in thermotolerance, apoptosis, and necrosis depending on the cell culture method; the three-dimensional (3D) culture system shows increased survival plausibly by activating the protective processes related to enhanced HSP70 expression as compared with the two-dimensional (2D) culture system at $45^{\circ} \mathrm{C}$ for $120 \mathrm{~min}$ [35].

Recently, we reported the thermotolerance of camel somatic cells to acute and chronic thermal stress, as evidenced by increased HSP expression, antioxidative response, and DNA repair enzymes [16]. Additionally, our previous results showed that camel cells tolerated acute hyperthermia and showed no alteration in the apoptosis-related mRNA transcripts P53, BAX, and BCL2); a proteomic investigation revealed the response of the cells with increased protein levels associated with autophagy to adapt to such lethal conditions [16].

Because of the essential role of HSPs in thermotolerance, we and other researchers proposed the phenomenon of "anastasis" to illustrate the survival response of thermotolerant cells [36-40]. Anastasis is a process of plasticity, resilience, or cellular resurrection from the brink of cell death [39] and could explain the difference in the thermotolerance of cells [41].

Additionally, there has been no reports regarding the differences between sheep and cow cell thermotolerance in vitro, which could reflect the acclimation, adaptation, or cellular response of the whole body to HS. Therefore, this study aimed to compare the effects of acute HS on cow and sheep skin-derived fibroblasts to provide a paradigm to elucidate the adaptability of large and small ruminant species to in vitro hyperthermia.

\section{Materials and Methods}

\subsection{Chemicals}

Chemicals were purchased from Sigma-Aldrich Corp. (St. Louis, MO, USA) unless otherwise stated.

\subsection{Skin Tissue Sampling and Culture}

Skin tissue samples were obtained from a local abattoir after five healthy cows (Holstein breed) and sheep (Naimi breed) were slaughtered. The whole ears of cows and sheep were transferred to the 
laboratory within $3 \mathrm{~h}$, cleaned with povidone iodide and 70\% ethanol, and shaved to remove the hair. Skin samples from the ear cutaneous pouch were chopped into small $0.5 \mathrm{~cm}^{2}$ pieces and soaked in sterile Dulbecco's phosphate buffered saline (DPBS) with a high concentration (10x) of antibiotic/antimycotic (penicillin $(500 \mathrm{IU} / \mathrm{mL} 0$, streptomycin $(500 \mu \mathrm{g} / \mathrm{mL})$, and amphotericin $(2.5 \mu \mathrm{g} / \mathrm{mL})$ ).

Skin-derived fibroblasts were isolated and cultured according to our previous protocols $[42,43]$. In brief, skin tissue pieces were transferred to $60 \mathrm{~mm}$ tissue culture plates using a sterile scalpel. The culture medium comprised DMEM (cat no. D6171, Sigma) containing glucose ( $4.5 \mathrm{~g} / \mathrm{L}$ ), HEPES (25 mM), L-glutamine (0.584 g/L), 10\% fetal bovine serum (FBS; Gibco, Waltham, MA, USA), and a $10 \times$ penicillin, streptomycin, and amphotericin solution and incubated at $37^{\circ} \mathrm{C}$ in an atmosphere of $5 \%$ $\mathrm{CO}_{2}$. The cultures were monitored microscopically to observe explant attachment and outgrowth of primary fibroblasts on day 10 of the culture. To maintain the primary cell culture, we removed the remaining parts of the skin explants and excluded the heterogeneous or mixed cell types according to our previous report [24].

\subsection{Cryopreservation and Thawing of Fibroblasts}

Cow and sheep primary cells were trypsinized with $0.25 \%$ trypsin-EDTA for 2 min at $37{ }^{\circ} \mathrm{C}$ and cells were centrifuged at $200 \times g$ for $2 \mathrm{~min}$. The pellets were resuspended in freezing medium (50\% DMEM, 10\% DMSO, and 40\% FBS (v/v)). Cell suspensions were distributed into cryogenic vials (at approximately $1 \times 10^{6}$ cells/vial), gradually frozen at $-80^{\circ} \mathrm{C}$, and transferred to a liquid nitrogen tank for long-term storage, until they were used for further experiments. Immediately before experiments, vials were quickly thawed at $37^{\circ} \mathrm{C}$, promptly mixed with the culture medium, and cultured in $60 \mathrm{~mm}$ culture dishes.

\subsection{Measuring Cellular Attachment and Cell Viability}

Images of cells (at least 10 fields) were captured pre- and post-exposure and analyzed using ImageJ 1.50i software (NIH, Bethesda, USA), after exposure was ended and cells were washed with PBS. To calculate the proportion of attached and non-attached cells, the percentage of attached cells in post-exposure to the initial cells, pre-exposure, was estimated. For the viability examination, cells were first trypsinized and the cell suspension was mixed at a 1:1 ratio with $0.4 \%$ trypan blue solution and incubated for $1 \mathrm{~min}$ at room temperature. Then, the cell suspension was loaded into a hemocytometer chamber and cells were counted to assess their viability using a traditional cell-counting method [17].

\subsection{Assessment of Cell Migration through Wound Healing Assay}

A wound healing assay was conducted according to our previous protocol [17,24]. Briefly, confluent cell monolayers were scraped into a straight line with a $200 \mu \mathrm{L}$ yellow pipette tip to create a wound. Cell debris and non-adherent cells were removed by washing with $2 \mathrm{~mL}$ of DMEM. Serial digital images of the wound were captured and the wound width was measured using ImageJ 1.50i software (NIH, Bethesda, USA) at different time points as referred to by the automated scale bar of the inverted microscope (Leica DMI4000 B; Leica Microsystems GMS GmbH, Wetzlar, Germany) for pixel analysis. The culture medium comprised DMEM, 10\% FBS, and a 1× penicillin/streptomycin/amphotericin solution. After creating the wound, cells were exposed to specific heat exposure as described below.

\subsection{Experimental Design}

Cell cultures and heat treatments were performed in 6-well culture plates after cell plating, attachment, and attaining 70\% to $80 \%$ confluency, and one well of each dish was used to evaluate the temporal cellular viability. Each experiment was repeated five times. 


\subsubsection{Effect of Acute Heat Shock on Primary Fibroblast Viability and Migratory Activity}

Cow and sheep primary cultured cells were exposed to acute heat shock $\left(45^{\circ} \mathrm{C}\right.$ for $\left.4 \mathrm{~h}\right)$, then the medium was changed with a fresh culture medium and cultured at $38^{\circ} \mathrm{C}$ for recovery from heat shock. The cell architecture was microscopically checked, and the cell viability and wound healing were compared against the control fibroblasts cultured at $38^{\circ} \mathrm{C}$ for $4 \mathrm{~h}$.

2.6.2. Effects of Acute Heat Shock on the Recovered Primary Fibroblast Viability and Migratory Activity

The primary fibroblasts that recovered and reached $70 \%$ to $80 \%$ confluency were exposed to acute heat shock $\left(45^{\circ} \mathrm{C}\right.$ for $4 \mathrm{~h}$ ), and then the medium was changed and cultured at $38^{\circ} \mathrm{C}$ for recovery. Cells were microscopically checked for architecture and growth. Cell viability and wound healing were recorded and compared to the control fibroblasts cultured at $38^{\circ} \mathrm{C}$ for $4 \mathrm{~h}$.

2.6.3. Impacts of Acute Heat Shock on the First Passage Fibroblast Viability and Migratory Activity

Trypsinized and subcultured fibroblast cells were exposed to acute heat shock at $45{ }^{\circ} \mathrm{C}$ for $4 \mathrm{~h}$.

2.6.4. Impact of Acute Heat Shock on the Cryopreserved Fibroblasts Viability and Migratory Activity

Cryopreserved fibroblasts were resuscitated and exposed to acute heat shock at $45^{\circ} \mathrm{C}$ for $4 \mathrm{~h}$.

In Figure S1, we provide an illustration of the experimental design.

\subsection{Relative Quantitative Polymerase Chain Reaction ( $q P C R$ )}

Total RNA extraction was isolated through a commercial kit (SV Total RNA Isolation System; Promega, Madison, WI, USA) following the manufacturer's instructions. Cultured cells (three replicates) were lysed with lysis buffer that was provided with the kit. The RNA quantity and quality were evaluated using a NanoDrop 2000 spectrophotometer (Thermo Fisher). Reverse transcription (RT) was performed according to our previous report [16], with 120 cycles of $16^{\circ} \mathrm{C}$ for $2 \mathrm{~min}, 37^{\circ} \mathrm{C}$ for $1 \mathrm{~min}$, and $50{ }^{\circ} \mathrm{C}$ for $1 \mathrm{~s}$, followed by a final inactivation at $85^{\circ} \mathrm{C}$ for $5 \mathrm{~min}$. RT reactions comprised $50 \mathrm{ng}$ of total RNA, and $5 \mu \mathrm{M}$ of random hexamers in a $20 \mu \mathrm{L}$ total reaction volume using an Amfivert cDNA Synthesis Master Mix (GenDEPOT Inc., TX, USA). Relative quantitative real-time PCR was performed using an automated thermal cycler (ViiA 7; Applied Biosystems). Reactions comprised $100 \mathrm{ng}$ of cDNA, $1 \mu \mathrm{M}$ forward and reverse primers, and 1× SYBR Green Premix (Applied Biosystems). Housekeeping genes GAPDH and $A C T B$ were used for normalization, and the fold changes of the target transcripts (HSP70, HSP90, P53, BAX, BCL2, and BECN1) were calculated using the $2^{-\Delta \Delta C t}$ method [24]. In all assays, reactions without cDNA and without RT resulted in no amplification. Thermal cycling conditions were $95^{\circ} \mathrm{C}$ for $5 \mathrm{~min}$, followed by 40 cycles of $95^{\circ} \mathrm{C}$ for $10 \mathrm{~s}, 60^{\circ} \mathrm{C}$ for $30 \mathrm{~s}$, and $72{ }^{\circ} \mathrm{C}$ for $30 \mathrm{~s}$. Information on primers is listed in Table S1.

\subsection{Statistical Analysis}

Three to five replicates were reported for each examined parameter. Cell viability data were presented as means \pm SEM, and values were analyzed using an ANOVA followed by Tukey's post-hoc test. Data on wound width, cellular attachment, and qPCR were presented as means \pm SEM, and values were analyzed using Student's $t$-test. Differences were considered significant at $p<0.05$. Pearson's linear correlation coefficients were calculated to determine the correlation $(R)$ between the means of different mRNA transcript expressions in the primary culture and first passage fibroblasts individually for cow and sheep cells, where $R> \pm 0.7$ were considered strong positive/negative linear relationships; $R> \pm 0.5$, moderate positive/negative linear relationships; and $R< \pm 0.5$, weak positive/negative linear relationships [42]. 


\section{Results}

\subsection{Effects of Acute Heat Shock on the Viability of Primary Fibroblasts in Cows and Sheep}

The primary culture of fibroblasts exhibited different behavior for recovery when exposed to acute heat shock. Cow cells regained proliferation and reached confluence after $96 \mathrm{~h}$ of recovery (Figure 1); however, sheep cells reached confluence after $192 \mathrm{~h}$ of recovery at $38^{\circ} \mathrm{C}$ (Figure 1 show the cell proliferation until $96 \mathrm{~h}$, although we did not show the entire results to be consistent in the species comparison). Interestingly, cells of the first passage in cows showed thermotolerance and regained the proliferation and confluency after $240 \mathrm{~h}$ of recovery, whereas sheep cells showed signs of degeneration and cells were easily removed during washing and changing of the culture medium (Figure S2). In contrast, primary cultured cells that recovered from the initial exposure showed cell degeneration and did not reach confluency, even after $240 \mathrm{~h}$ of recovery (Figure 1).
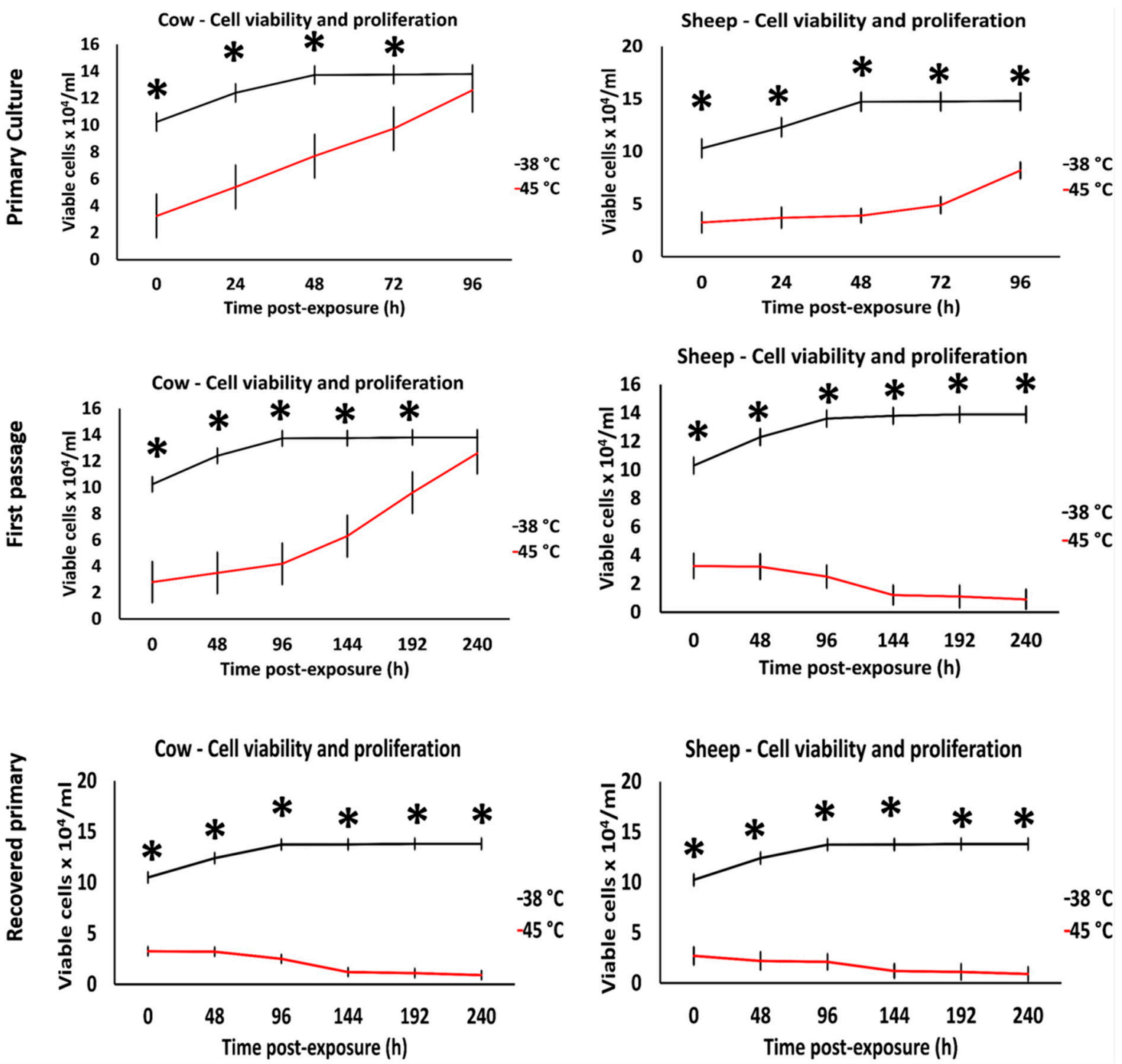

Figure 1. Effects of acute heat stress $\left(45^{\circ} \mathrm{C}\right.$ for $\left.4 \mathrm{~h}\right)$ on cow and sheep cell viability. After the end of exposure $(0 \mathrm{~h})$, cells were recovered at $38{ }^{\circ} \mathrm{C}$ in a humid atmosphere of $5 \% \mathrm{CO}_{2}$ and examined daily for cell viability until they reached $100 \%$ confluency $\left(\sim 13 \times 10^{4}\right.$ cells $\left./ \mathrm{mL}\right)$. Data are presented as means \pm SEM, values of the same timings were analyzed using Student's $t$-test, and asterisks $\left(^{*}\right)$ indicate significant differences at $p<0.05$. 


\subsection{Effects of Acute Heat Shock on the Migratory Activity of Primary Fibroblasts in Cows and Sheep}

Figures 2 and 3 represent the comparison between the tolerance of primary cultured fibroblasts in cows and sheep when exposed to acute heat shock $\left(45^{\circ} \mathrm{C}\right.$ for $\left.4 \mathrm{~h}\right)$. Cow fibroblasts showed rapid wound closure (cell scratch assay) as compared with the sheep fibroblasts, $96 \mathrm{~h}$ vs. $192 \mathrm{~h}$, respectively. The high magnification of the cells showed that sheep cells lost the attachment to the culture dish at a relatively higher proportion than that of the cow cells (Figure S2).

\section{Control $38{ }^{\circ} \mathrm{C} / 4 \mathrm{~h}$}
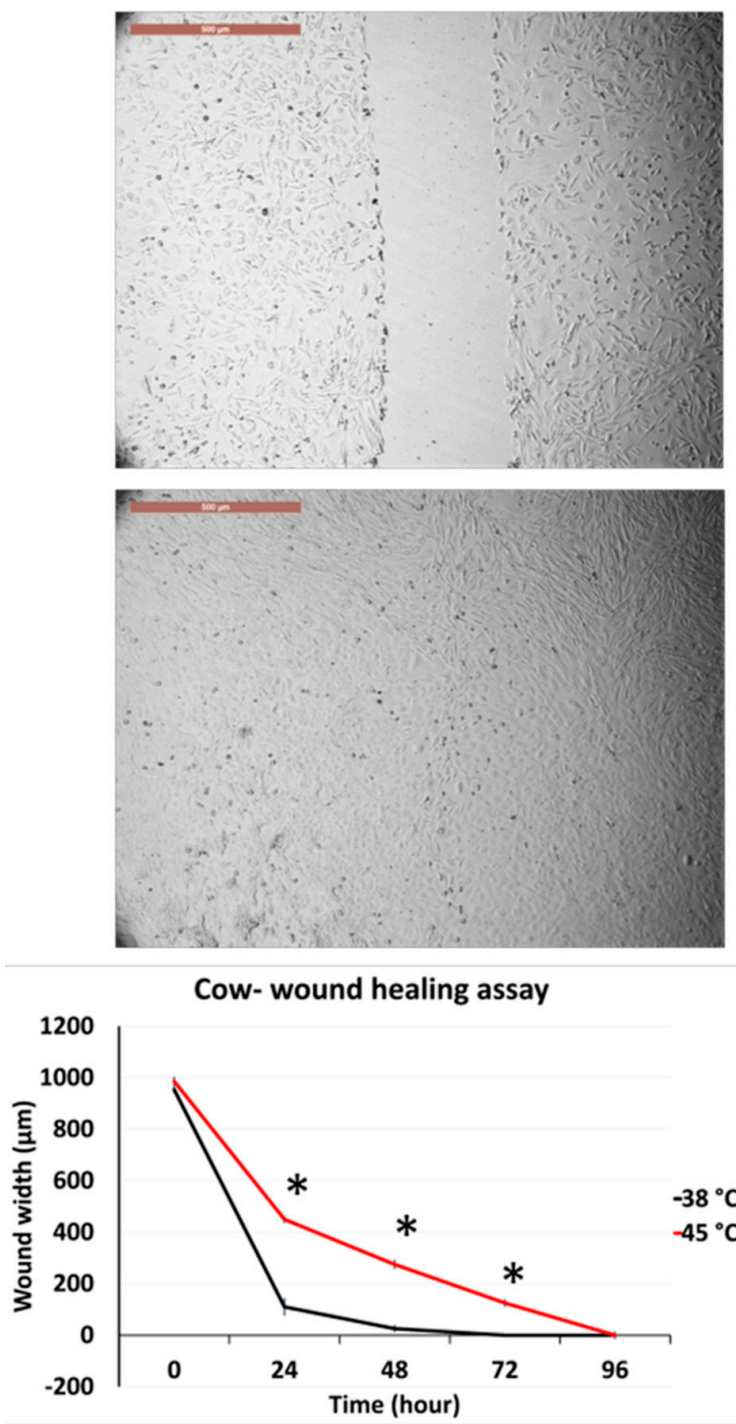

$\mathrm{HS} 45^{\circ} \mathrm{C} / 4 \mathrm{~h}$

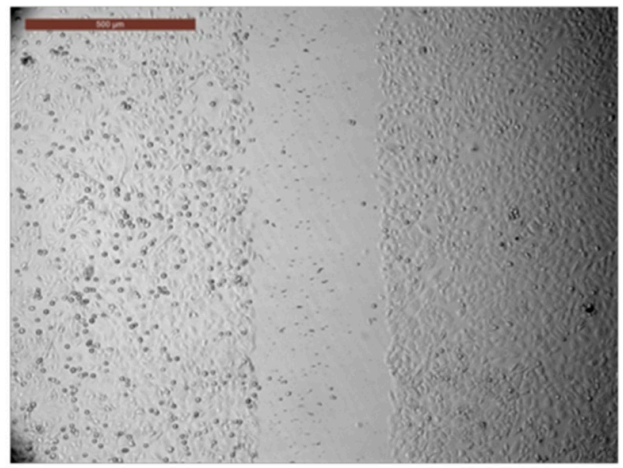

\section{$4 \mathrm{~h}$}

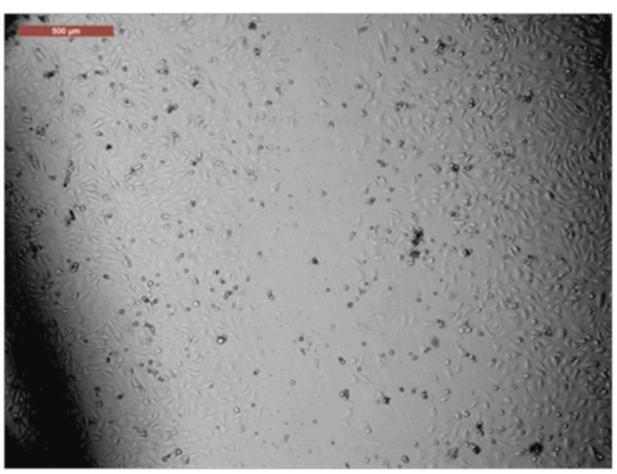

$48 \mathrm{~h}$

Recov

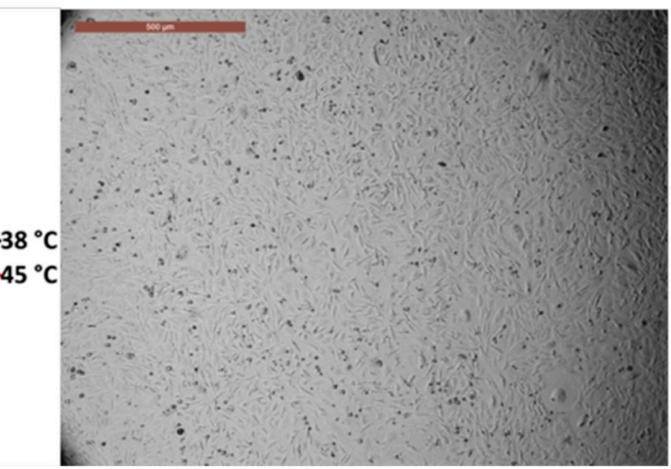

$96 \mathrm{~h}$

Recov

Figure 2. Wound healing (cell scratch) assay for cow primary cultured fibroblasts exposed to $45^{\circ} \mathrm{C}$ for $4 \mathrm{~h}$ and control cells $\left(38^{\circ} \mathrm{C}\right.$ for $4 \mathrm{~h}$ ). Cells were incubated under the required conditions, recovered at $38^{\circ} \mathrm{C}$, and monitored daily for wound closure. Scale bar $=500 \mu \mathrm{m}$. Data are presented as means $\pm \mathrm{SEM}$, values of the same timings were analyzed using Student's $t$-test, and asterisks $\left(^{*}\right)$ indicate significant differences at $p<0.05$. 
Control $38^{\circ} \mathrm{C} / 4 \mathrm{~h}$
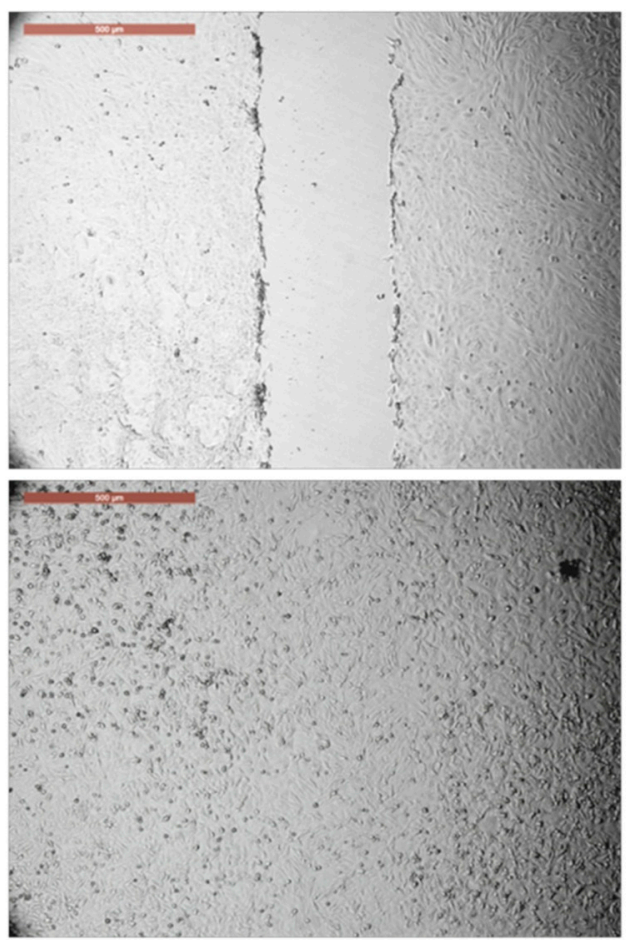

Sheep- Wound healing assay

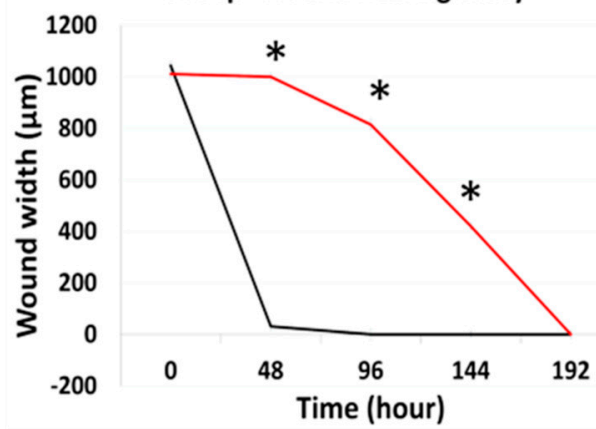

HS $45{ }^{\circ} \mathrm{C} / 4 \mathrm{~h}$

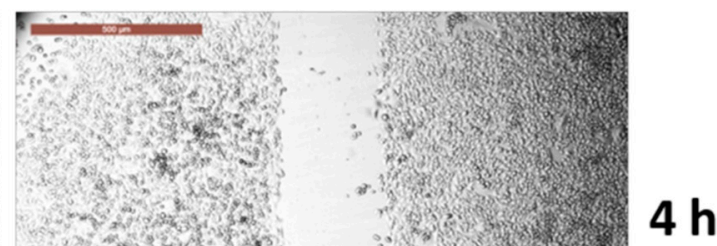

$4 \mathrm{~h}$

$48 \mathrm{~h}$

Recov

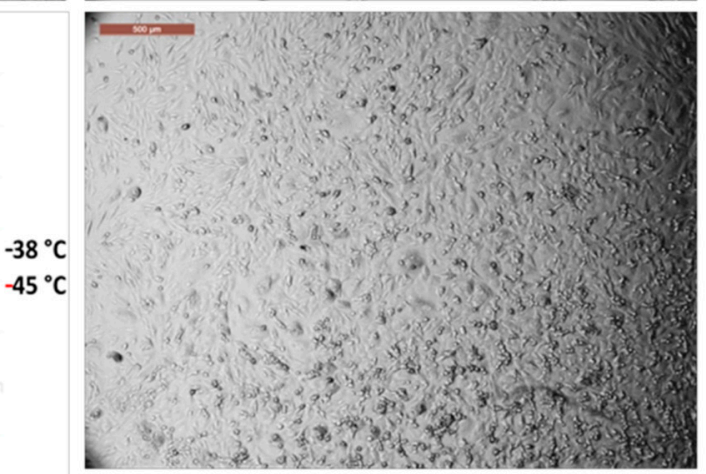

$192 \mathrm{~h}$

Recov

Figure 3. Wound healing (cell scratch) assay for sheep primary cultured fibroblasts exposed to $45^{\circ} \mathrm{C}$ for $4 \mathrm{~h}$ and control cells $\left(38^{\circ} \mathrm{C}\right.$ for $4 \mathrm{~h}$ ). Cells were incubated under the required conditions, recovered at $38^{\circ} \mathrm{C}$, and monitored daily for wound closure. Scale bar $=500 \mu \mathrm{m}$. Data are presented as means \pm SEM, values of the same timings were analyzed using Student's $t$-test, and asterisks $\left(^{*}\right)$ indicate significant differences at $p<0.05$.

3.3. Effects of Acute Heat Shock on the Migratory Activity of the Recovered Primary Fibroblasts in Cows and Sheep

Figures 4 and 5 represent the comparison between the tolerance of the primary cultured fibroblasts in cows and sheep that were recovered from previous exposure and re-exposed to acute heat shock $\left(45^{\circ} \mathrm{C}\right.$ for $4 \mathrm{~h}$ ). Both cells showed degeneration and failed to close the wounds even after $240 \mathrm{~h}$ of recovery. However, high magnification of the cells showed that sheep cells lost their attachment to the culture dish at a relatively higher proportion as compared with that of the cow cells (Figure S3), but with the progression of time, the cell viability decreased and the cells were easily detached during routine washing and medium changes. 




Figure 4. Wound healing (cell scratch) assay for cow primary cultured fibroblasts that recovered after exposure to $45^{\circ} \mathrm{C}$ for $4 \mathrm{~h}$ and reached confluency as compared with the control cells $\left(38^{\circ} \mathrm{C}\right.$ for $4 \mathrm{~h}$ ). The wounds were created after cell recovery at confluency. Cells were incubated under the required conditions, recovered at $38{ }^{\circ} \mathrm{C}$, and monitored daily for wound closure. Scale bar $=500 \mu \mathrm{m}$. Data are presented as means $\pm \mathrm{SEM}$, values of the same timings were analyzed using Student's $t$-test, and asterisks $\left({ }^{*}\right)$ indicate significant differences at $p<0.05$. 
Control $38^{\circ} \mathrm{C} / 4 \mathrm{~h}$
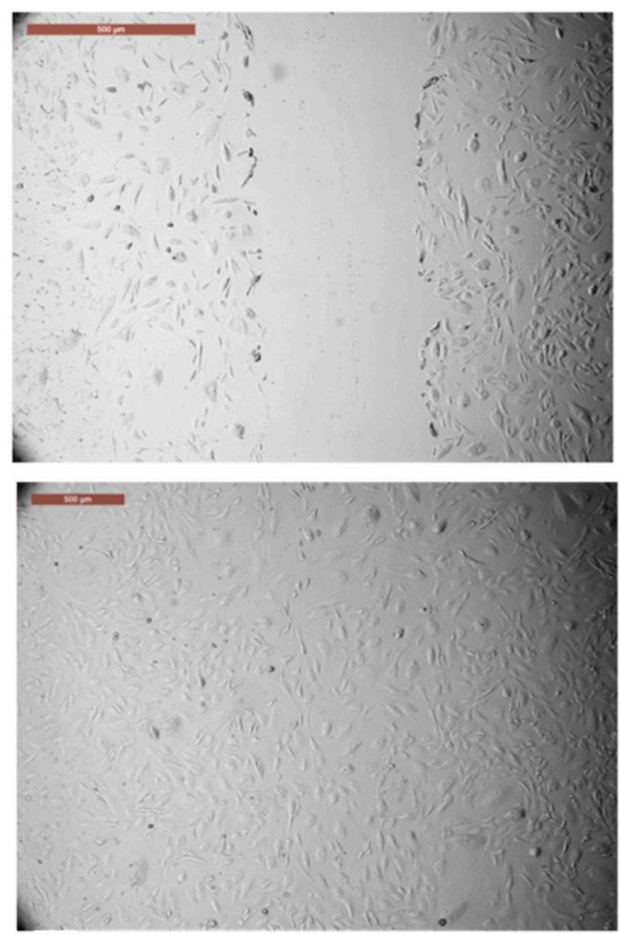

Sheep- Wound healing assay



HS $45^{\circ} \mathrm{C} / 4 \mathrm{~h}$



$4 \mathrm{~h}$

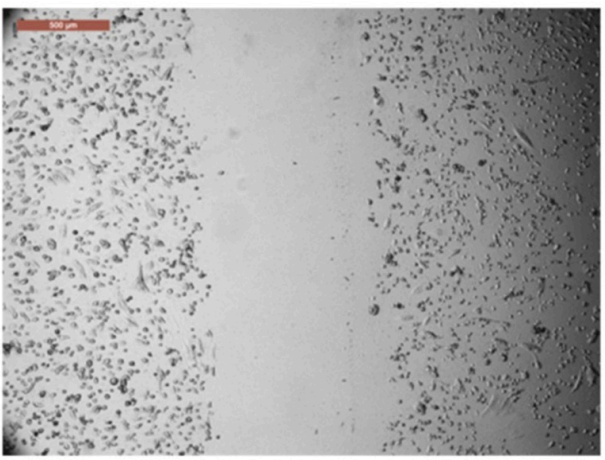

$48 \mathrm{~h}$

Recov

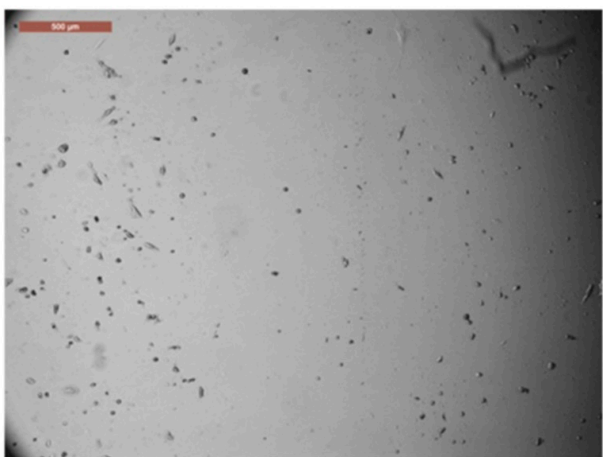

$240 \mathrm{~h}$

Recov

Figure 5. Wound healing (cell scratch) assay for sheep primary cultured fibroblasts that recovered after exposure to $45^{\circ} \mathrm{C}$ for $4 \mathrm{~h}$ and reached confluency as compared with the control cells $\left(38^{\circ} \mathrm{C}\right.$ for $\left.4 \mathrm{~h}\right)$. The wounds were created after cell recovery at confluency. Cells were incubated under the required conditions, recovered at $38{ }^{\circ} \mathrm{C}$, and monitored daily for wound closure. Scale bar $=500 \mu \mathrm{m}$. Data are presented as means $\pm \mathrm{SEM}$, values of the same timings were analyzed using Student's $t$-test, and asterisks $\left({ }^{*}\right)$ indicate significant differences at $p<0.05$.

\subsection{Effects of Acute Heat Shock on the Migratory Activity of the First Passage Cow and Sheep Fibroblasts}

Figures 6 and 7 represent the comparison between the tolerance of the first passage cow and sheep fibroblasts exposed to acute heat shock $\left(45^{\circ} \mathrm{C}\right.$ for $\left.4 \mathrm{~h}\right)$. Cow fibroblasts showed wound closure after $240 \mathrm{~h}$ from recovery at $38^{\circ} \mathrm{C}$, whereas sheep fibroblasts failed to attain wound healing at this time and showed degenerative changes. High magnification of the cells showed that sheep cells lost their attachment to the culture dish at a relatively higher proportion than did cow cells (Figure S4). 
Control $38^{\circ} \mathrm{C} / 4 \mathrm{~h}$
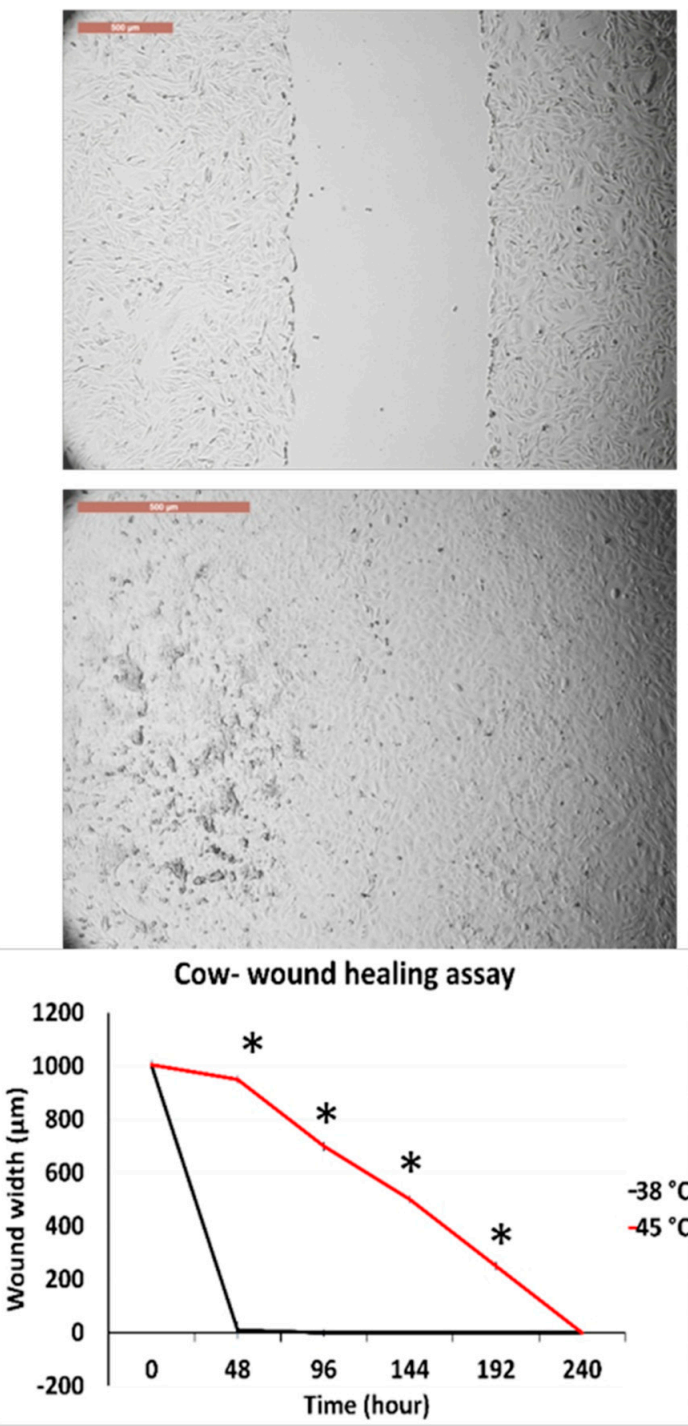

HS $45^{\circ} \mathrm{C} / 4 \mathrm{~h}$

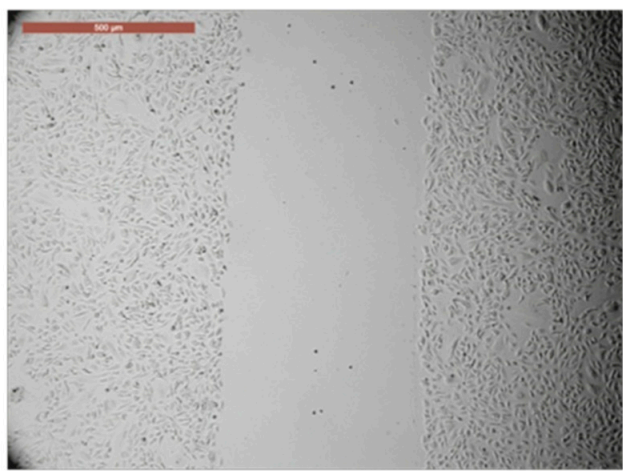

$4 \mathrm{~h}$

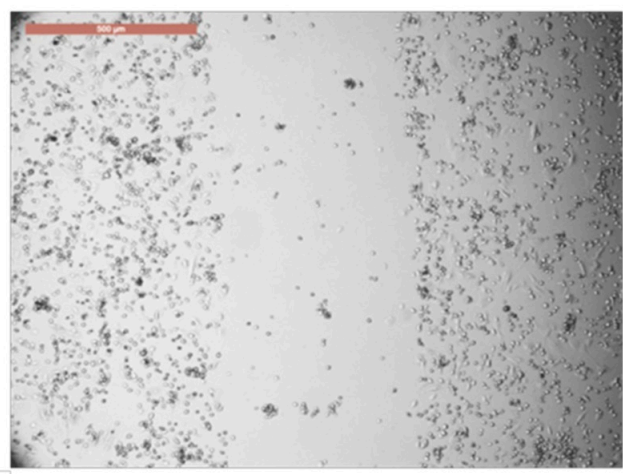

$48 \mathrm{~h}$

Recov

\section{$240 \mathrm{~h}$} Recov

Figure 6. Wound healing (cell scratch) assay for cow first passage fibroblasts exposed to $45^{\circ} \mathrm{C}$ for $4 \mathrm{~h}$ and control cells $\left(38^{\circ} \mathrm{C}\right.$ for $4 \mathrm{~h}$ ). Cells were incubated under the required conditions, recovered at $38^{\circ} \mathrm{C}$, and monitored daily for wound closure. Scale bar $=500 \mu \mathrm{m}$. Data are presented as means $\pm \mathrm{SEM}$, values of the same timings were analyzed using Student's $t$-test, and asterisks $\left(^{*}\right)$ indicate significant differences at $p<0.05$. 
Control $38{ }^{\circ} \mathrm{C} / 4 \mathrm{~h}$
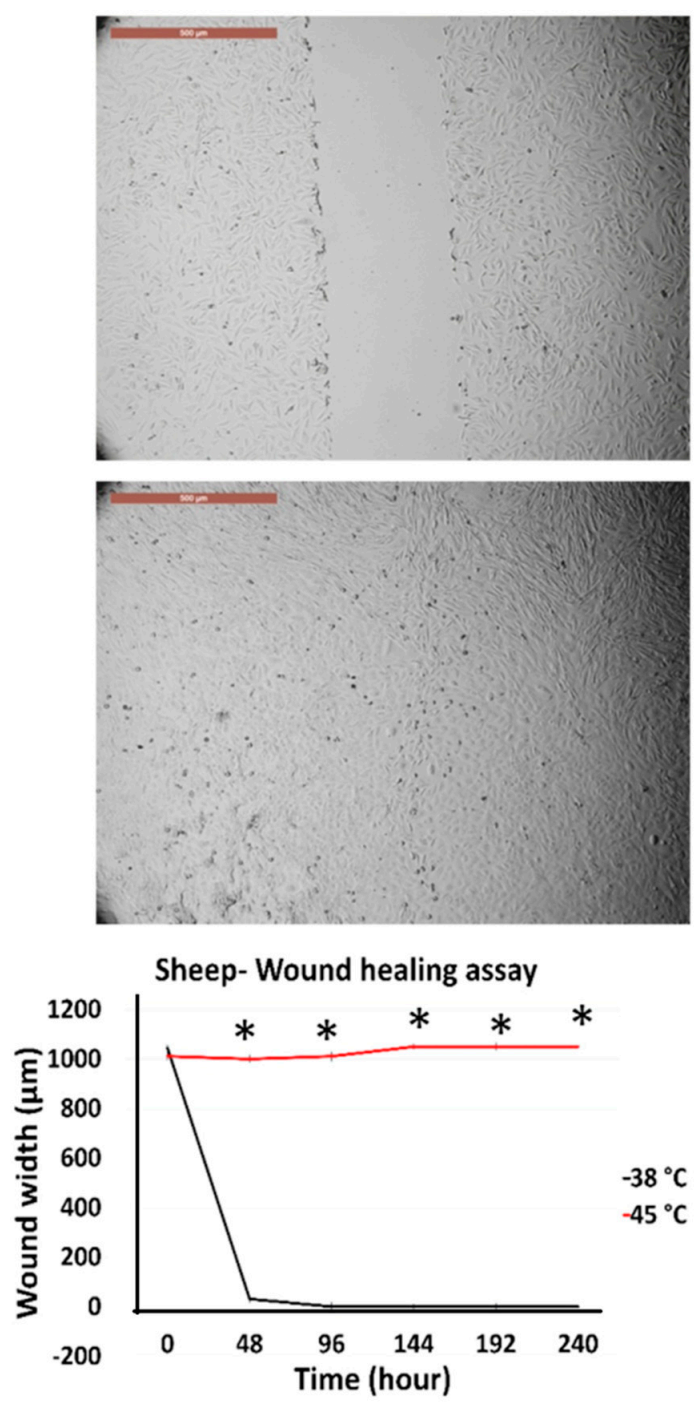

$\mathrm{HS} 45^{\circ} \mathrm{C} / 4 \mathrm{~h}$

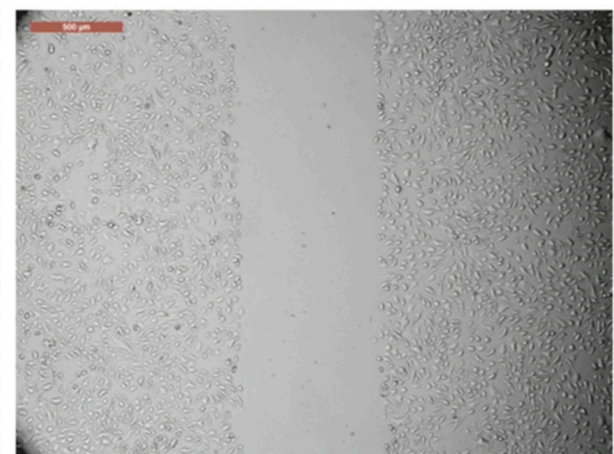

$4 \mathrm{~h}$

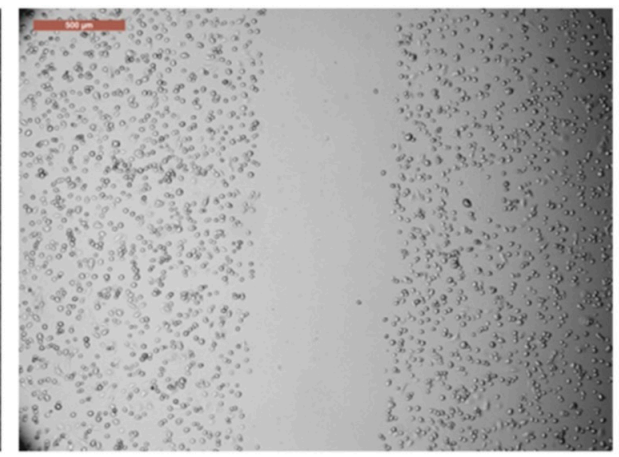

$48 \mathrm{~h}$

Recov

$240 \mathrm{~h}$

Recov

Figure 7. Wound healing (cell scratch) assay for sheep first passage fibroblasts exposed to $45^{\circ} \mathrm{C}$ for $4 \mathrm{~h}$ and control cells $\left(38^{\circ} \mathrm{C}\right.$ for $4 \mathrm{~h}$ ). Cells were incubated under the required conditions, recovered at $38^{\circ} \mathrm{C}$, and monitored daily for wound closure. Scale bar $=500 \mu \mathrm{m}$. Data are presented as means $\pm \mathrm{SEM}$, values of the same timings were analyzed using Student's $t$-test, and asterisks $\left.{ }^{*}\right)$ indicate significant differences at $p<0.05$.

\subsection{Effects of Acute Heat Shock on the Viability of Cryopreserved Fibroblasts in Cows and Sheep}

Cryopreserved cow cells showed better thermotolerance than did sheep cells exposed to acute heat shock $\left(45^{\circ} \mathrm{C}\right.$ for $2 \mathrm{~h}$ ). Viable cells dropped to $1.7 \pm 0.5 \mathrm{vs.} 7.1 \pm 0.7 \times 10^{4} / \mathrm{mL}$ as compared with the control cells at $10.2 \pm 0.5$ vs. $10.6 \pm 0.6 \times 10^{4} / \mathrm{mL}$ in sheep and cows, respectively $(p<0.05)$ (Figure 8 ). Additionally, cow cells showed an increased proportion of attachment as compared with sheep cells $(53.4 \pm 3.6 \%$ vs. $16.6 \pm 4.3 \%$, respectively, $p<0.05$ ) (Figure 8 ). 


\section{Control $38^{\circ} \mathrm{C} / 2 \mathrm{~h}$}
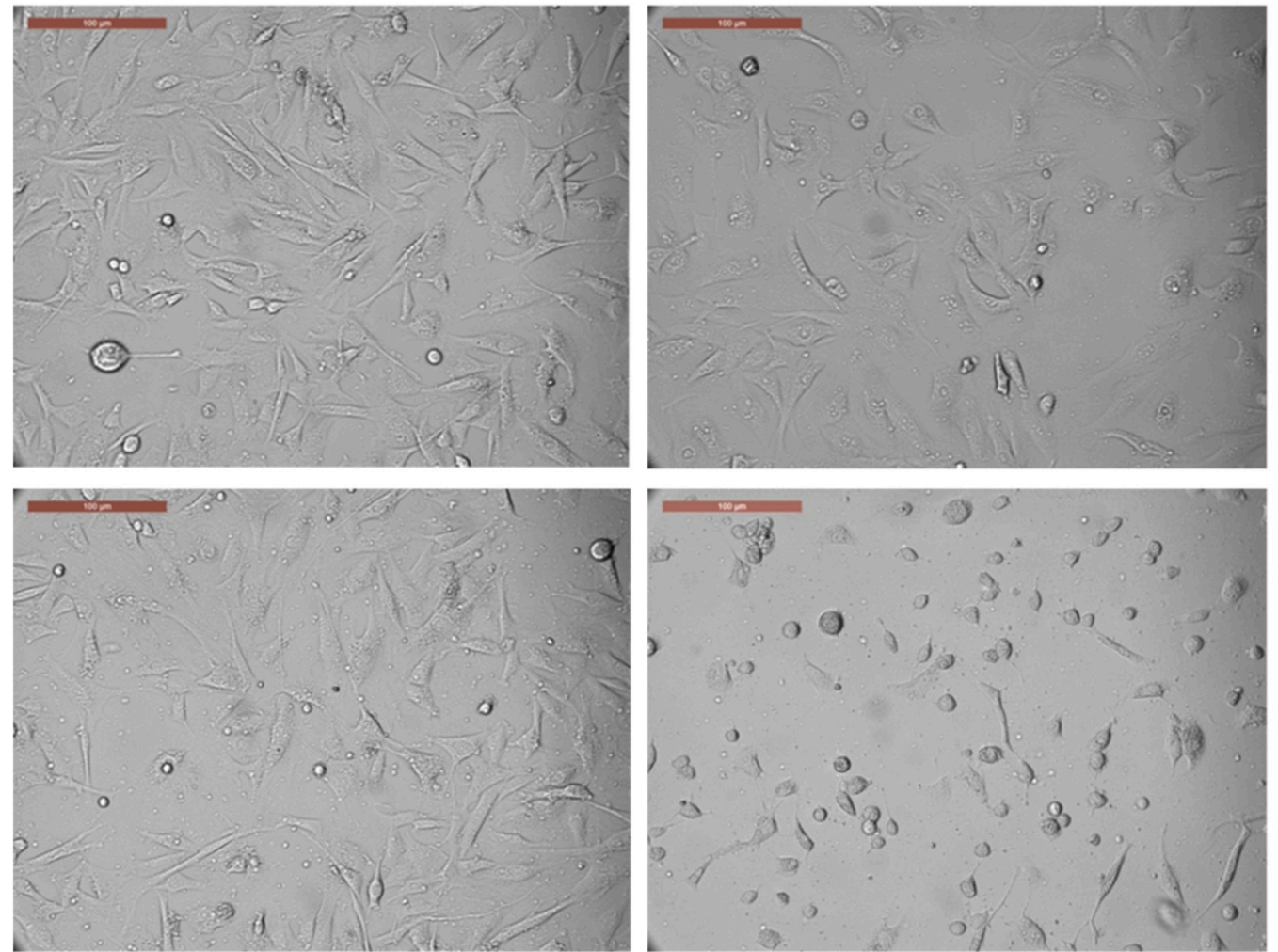

Cow

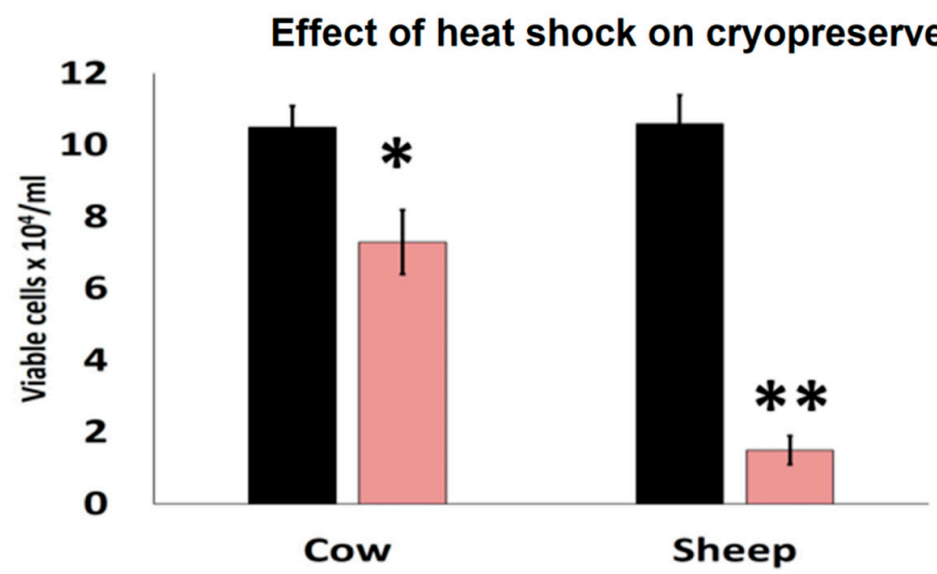

\section{Sheep}

Figure 8. High magnification of cow and sheep cryopreserved fibroblasts after exposure to acute heat shock ( $4{ }^{\circ} \mathrm{C}$ for $2 \mathrm{~h}$ ). In cow cells, several cells remained attached to the cell culture dish and retained a spindle morphology (arrows), whereas, in sheep, the majority of the cells lost their architecture (arrows) and attachment to the culture dish. The numbers of attached and non-attached cells were counted and analyzed with ImageJ software and the data were analyzed by Student's $t$-test. Scale bar $=100 \mu \mathrm{m}$. The graph describes the effects on cell viability, data are presented as means \pm SEM, values of the same timings were analyzed using a Student's $t$-test, and asterisks $\left(^{*}\right)$ and $\left({ }^{* *}\right)$ indicate significant changes at $p<0.05$ and $p<0.01$, respectively. 
3.6. Effects of Acute Heat Shock on the Expression of mRNA Transcripts in Primary Culture and First Passage Cow and Sheep Fibroblasts

In both cow and sheep primary cultured fibroblasts (Figure 9A,B), HSP70 and HSP90 showed increased expression in heat-shocked cells as compared with the control cells. However, BECN1 showed significant decreases in both cell types. Paradoxically, BAX and BAX/BCL2 showed significant increases in cow primary cultured fibroblasts as compared with that in sheep cells. BCL2 exhibited no change in sheep cells, whereas cow cells showed a decreased level. P53 showed a significant increase in sheep cells as compared with that in cow and control cells. In the first passage (Figure 9C,D), cow cells still showed the increased expression of both HSP70 and HSP90, whereas sheep cells showed the increased expression of only HSP90. P53 exhibited more than a 16-fold increase in sheep cells as compared with the lack of change in cow cells. BAX and BAX/BCL2 showed a significant increase in both cell types, whereas BECN1 exhibited a significant decrease in cow cells. BCL2 exhibited significant decreases in both cells. In cow cells (Table S2), HSP90 expression had a strong positive correlation with HSP70, BAX, and BAX/BCL2 expression, whereas it showed a strong negative correlation with P53, BCL2, and BECN1. Similarly, HSP70 expression had a strong negative correlation with BCL2 and BECN1 and a moderate positive correlation with BAX/BCL2. Conversely, P53 had a strong positive correlation with BCL2, a strong negative correlation with BAX and BAX/BCL2, and a moderate positive correlation with BECN1. In contrast, BAX showed a strong negative correlation with BCL2 and a strong negative correlation with BECN1. In sheep cells, HSP90 had a strong positive correlation with P53, a moderate positive correlation with BAX, and a moderate negative correlation with BCL2. However, HSP70 had a moderate negative correlation with BAX and a strong negative correlation with BECN1. In addition, P53 exhibited a strong positive correlation with BAX and BECN1 and a strong negative correlation with BCL2 (Table S3). 

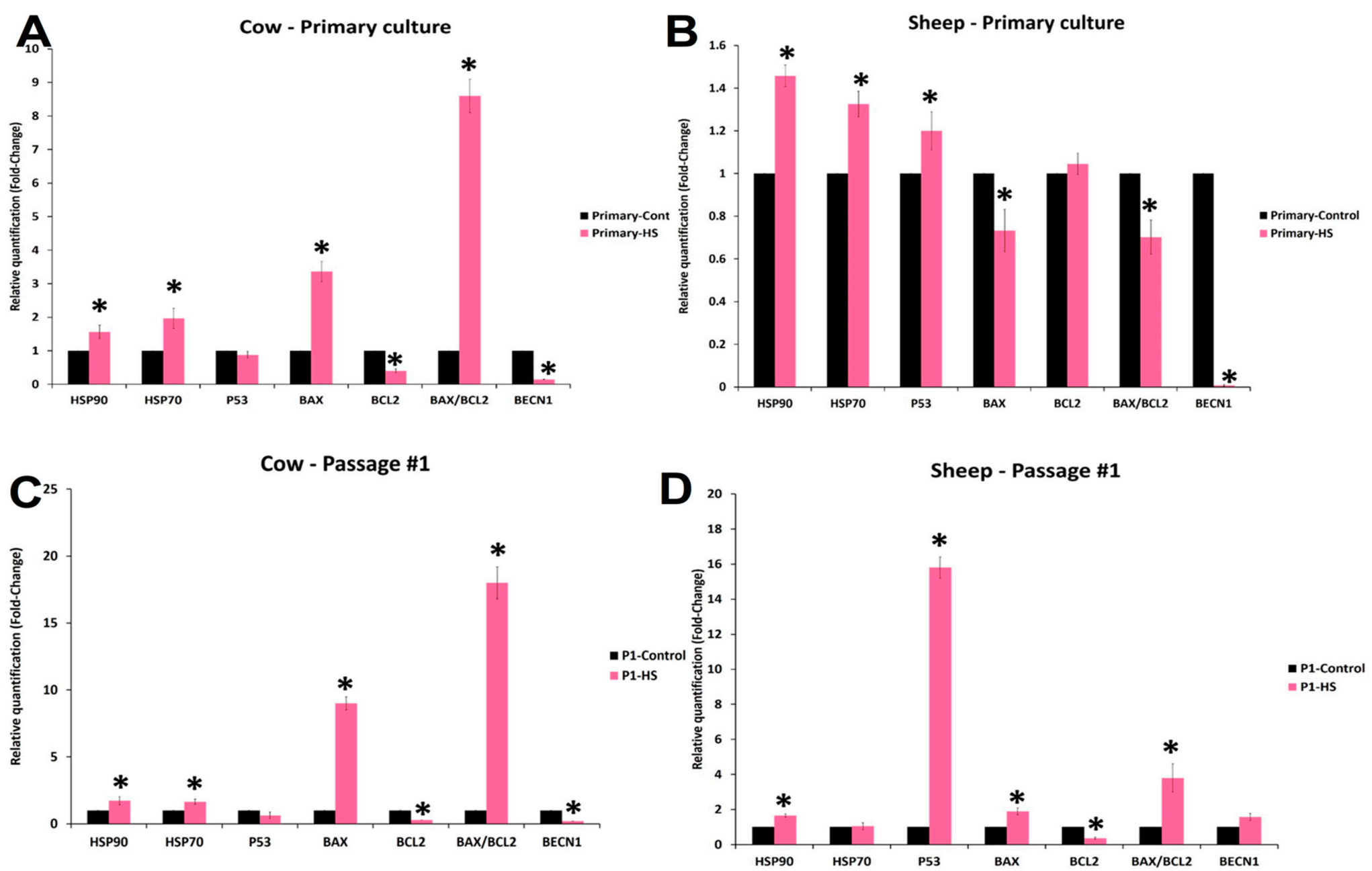

Figure 9. Relative quantitative PCR and fold change of selected mRNA transcript expressions in cow and sheep fibroblasts of different passages exposed to acute heat shock $\left(45^{\circ} \mathrm{C}\right.$ for $\left.4 \mathrm{~h}\right) .(\mathbf{A}, \mathbf{B})$ show the primary cultured fibroblasts in cows and sheep, respectively; (C,D)show the first passage (P1) fibroblasts in cows and sheep, respectively. Data are presented as means \pm SEM, values of the same mRNA transcript in control and heat-shocked cells were analyzed using Student's $t$-test, and asterisks $\left(^{*}\right)$ indicate significant differences at $p<0.05$. 


\section{Discussion}

The current results represent a continuation of our experiments that were performed to compare the species differences in in vitro thermotolerance to elucidate species adaptability and acclimation to extreme heat exposure $[16,17,24,34]$. Recently, we showed that camel cells better tolerated chronic heat shock $\left(45^{\circ} \mathrm{C}\right.$ for $20 \mathrm{~h}$ ) than porcine cells [16], and the results of this study revealed that cow cells were more tolerant to acute heat shock than sheep cells on the primary and first passage level, as well as for cryopreserved fibroblasts. Cell viability, proliferation, attachment to culture dishes, and ability to close the wound were all significantly decreased in sheep cells as compared with in cow cells.

To investigate these mechanisms, we measured the fold changes of some mRNA transcripts associated with heat shock response (HSP70, HSP90), apoptosis (P53, BAX, and BCL2), and autophagy (BECN1).

It is difficult to compare the species differences in terms of gene expression; however, in the current approach, we measured the relative fold changes in the expression of the same mRNA transcripts within the same species and compared its expression pattern with those of the other species, in accordance with a recent report [43].

Although the BAX/BCL2 ratio was elevated in cow fibroblasts, the P53 transcript expression was significantly elevated in both the primary culture and first passage fibroblasts of sheep cells as compared with that in cow cells. Correlation analysis showed that P53 exhibited a strong positive correlation with apoptosis (BAX) and autophagy (BECN1)-related mRNAs. However, there was a strong positive correlation of P53 with HSP90 in sheep as compared with a strong negative correlation in cows. This result indicated that cow cells responded with HSP90 and HSP70 in a greater proportion than did sheep cells.

In bovine cells, it has been reported that hyperthermia caused somatic cell apoptosis because of an imbalance in the BAX/BCL2 pathway in favor of the pro-apoptotic protein BAX [44,45]. Moreover, stress signals can trigger the increase in P53 expression for cell cycle arrest, DNA repair, and apoptosis [46]. Conversely, the co-increase in the expression of HSP90 and HSP70 in the first passage cow fibroblasts could be the reason behind the relative thermotolerance of cow cells as compared with that of sheep fibroblasts in the first passage (Figure 9C and Table S2). HSP70 inhibits apoptosis by blocking the recruitment of procaspase- 9 to the cytochrome c apoptosome complex through conformational changes that render procaspase-9 binding less effective [47]. Therefore, P53 can be protected from thermal unfolding by HSPs, and this protection can require reciprocal interactions with different HSP domains $[48,49]$. It is apparent from the current study that the elevated P53 expression could reduce cell viability and thermotolernace in sheep cells and this could be a result of the relatively high expression of both HSP70 and HSP90 in cow cells as compared with in sheep cells. Additionally, P53 showed a moderate and strong positive correlation with the autophagy gene (BECN1) in cow and sheep cells, respectively, which indicated that the activation of autophagy is a part of the negative feedback and protective function of P53 [50].

Surprisingly, cow and sheep cells that were recovered from the heat shock and re-exposed to similar conditions lost their coping capabilities and resistance to heat shock, which indicated that acclimation or adaptation is not likely to be achieved in vitro under our experimental conditions.

Species and breed differences in thermotolerance have been reported in both sheep and cows. The cell viability in the Pelibuey breed was higher than that in the Suffolk breed after hyperthermia, an effect that could be attributed to an HSP-70-related mechanism [15]. In contrast, thermotolerance and HSP90 expression were elevated in breeds adapted to warm climates as compared with breeds from colder origins, such as Sahiwal (Bos indicus) and Frieswal (Bos indicus $\times$ Bos taurus) [13], or between Zebu and crossbreed cattle [14], respectively.

On the basis of the current results, we confirm our previous findings that trypsin could be an additional stress to the cells in vitro [24]. Furthermore, exposure of cells to trypsin potentiated the effects of heat on cellular damage [51,52]. Furthermore, trypsin has been found to alter cell membrane surface proteins that are responsible for the extracellular matrix and metabolic pathways [53,54]. 
Trypsin is the most common enzyme used for cell passaging and routine cell culture protocols; hence, it is important to find an alternative for cell dissociation in experiments studying cellular responses to heat shock. Moreover, cryopreservation showed the reduced thermotolerance of sheep cells, which could be an additional stress to the cells. Cryopreservation has been proven to be a successful approach for the long-term storage of biological material; however, there is growing evidence of its potentially damaging effects at the molecular level of cells, such as metabolic perturbations, impaired mitochondrial function, and gene expression [55-57]. The effects of cryopreservation could also be potentiated by initial cell dispersion with trypsin, which causes additional stress to the cells.

\section{Conclusions}

This study investigated the thermotolerance of cow and sheep fibroblasts to acute hyperthermia $\left(45^{\circ} \mathrm{C}\right.$ for $\left.4 \mathrm{~h}\right)$. Cow cells showed greater resistance than sheep cells in terms of cell viability, proliferation, and migratory activities, as well as the maintenance of HSP90 and HSP70 expression to overcome the damaging effects of hyperthermia. However, further studies are necessary to analyze the evolutionary and molecular mechanisms controlling different gene and protein expressions associated with thermotolerance in these types of cells.

Supplementary Materials: The following are available online at http://www.mdpi.com/2076-2615/10/4/545/s1, Figure S1: Experimental design flowchart; Figure S2: High magnification of cow and sheep primary cultured fibroblasts after exposure to acute heat shock $\left(4{ }^{\circ} \mathrm{C}\right.$ for $\left.4 \mathrm{~h}\right)$; Figure S3: High magnification of the recovered cow and sheep primary fibroblasts when re-exposed to acute heat shock $\left(4^{\circ} \mathrm{C}\right.$ for $\left.4 \mathrm{~h}\right)$; Figure S4: High magnification of the first passage cow and sheep fibroblasts exposed to acute heat shock ( $4^{\circ} \mathrm{C}$ for $4 \mathrm{~h}$ ); Table S1: Primers used for relative quantitative PCR; Table S2: Correlation coefficient between fold changes of different mRNA transcripts in primary cultured and first passage fibroblasts in cows; Table S3: Correlation coefficient between fold changes of different mRNA transcript in primary cultured and first passage fibroblasts in sheep.

Author Contributions: Conceptualization, I.M.S. and A.A.-A.S.; methodology, I.M.S., H.A.T., and A.M.Z.; investigation, I.M.S. and H.A.T.; data curation, I.M.S., and A.E.N.; writing-review and editing, I.M.S. and A.N.A.; supervision, I.M.S.; project administration, I.M.S.; funding acquisition, I.M.S. All authors have read and agreed to the published version of the manuscript.

Funding: The authors extend their appreciation to the Deanship of Scientific Research at King Saud University for funding this work through research group RG-1438-018.

Acknowledgments: The authors extend their appreciation to the RSSU, Deanship of Scientific Research at King Saud University for technical assistance.

Conflicts of Interest: The authors declare that they have no conflicts of interest.

\section{References}

1. Aggarwal, A.; Upadhyay, R. Heat Stress and Milk Production. In Heat Stress and Animal Productivity; Springer: Delhi, India, 2013; pp. 53-77. [CrossRef]

2. Aggarwal, A.; Upadhyay, R. Heat Stress and Reproduction. In Heat Stress and Animal Productivity; Springer: Delhi, India, 2013; pp. 79-111. [CrossRef]

3. Abdelnour, S.A.; Abd El-Hack, M.E.; Khafaga, A.F.; Arif, M.; Taha, A.E.; Noreldin, A.E. Stress biomarkers and proteomics alteration to thermal stress in ruminants: A review. J. Therm. Biol. 2019, 79, 120-134. [CrossRef]

4. Lees, A.M.; Sejian, V.; Wallage, A.L.; Steel, C.C.; Mader, T.L.; Lees, J.C.; Gaughan, J.B. The impact of heat load on cattle. Animals 2019, 9, 322. [CrossRef] [PubMed]

5. Das, R.; Sailo, L.; Verma, N.; Bharti, P.; Saikia, J.; Imtiwati; Kumar, R. Impact of heat stress on health and performance of dairy animals: A review. Vet. World 2016, 9, 260-268. [CrossRef] [PubMed]

6. Boni, R. Heat stress, a serious threat to reproductive function in animals and humans. Mol. Reprod. Dev. 2019, 86, 1307-1323. [CrossRef] [PubMed]

7. Ross, T.T.; Goode, L.; Linnerud, A.C. Effects of high ambient temperature on respiration rate, rectal temperature, fetal development and thyrold gland activity in tropical and temperate breeds of sheep. Theriogenology 1985, 24, 259-269. [CrossRef]

8. Horowitz, M. From molecular and cellular to integrative heat defense during exposure to chronic heat. Comp. Biochem. Physiol. A Mol. Integr. Physiol. 2002, 131, 475-483. [CrossRef] 
9. Alhidary, I.A.; Shini, S.; Al Jassim, R.A.M.; Gaughan, J.B. Physiological responses of Australian Merino wethers exposed to high heat load. J. Anim. Sci. 2012, 90, 212-220. [CrossRef]

10. Sejian, V.; Bhatta, R.; Gaughan, J.B.; Dunshea, F.R.; Lacetera, N. Review: Adaptation of animals to heat stress. Animal 2018, 12, s431-s444. [CrossRef]

11. Kamwanja, L.A.; Chase, C.C.; Gutierrez, J.A.; Guerriero, V.; Olson, T.A.; Hammond, A.C.; Hansen, P.J. Responses of bovine lymphocytes to heat shock as modified by breed and antioxidant status. J. Anim. Sci. 1994, 72, 438-444. [CrossRef]

12. Paula-Lopes, F.F.; Al-Katanani, Y.M.; Rivera, R.M.; Tekin, S.; Majewski, A.C.; Ocon, O.M.; Olson, T.A.; Hansen, P.J. Genetic divergence in cellular resistance to heat shock in cattle: Differences between breeds developed in temperate versus hot climates in responses of preimplantation embryos, reproductive tract tissues and lymphocytes to increased culture temperatures. Reproduction 2003, 125, 285-294. [CrossRef]

13. Deb, R.; Sajjanar, B.; Singh, U.; Kumar, S.; Singh, R.; Sengar, G.; Sharma, A. Effect of heat stress on the expression profile of Hsp90 among Sahiwal (Bos indicus) and Frieswal (Bos indicus $\times$ Bos taurus) breed of cattle: A comparative study. Gene 2014, 536, 435-440. [CrossRef] [PubMed]

14. Maibam, U.; Hooda, O.K.; Sharma, P.S.; Upadhyay, R.C.; Mohanty, A.K. Differential level of oxidative stress markers in skin tissue of zebu and crossbreed cattle during thermal stress. Livest. Sci. 2018, 207, 45-50. [CrossRef]

15. Romero, R.D.; Montero Pardo, A.; Montaldo, H.H.; Rodríguez, A.D.; Hernández Cerón, J. Differences in body temperature, cell viability, and HSP-70 concentrations between Pelibuey and Suffolk sheep under heat stress. Trop. Anim. Health Pro. 2013, 45, 1691-1696. [CrossRef] [PubMed]

16. Saadeldin, I.M.; Abdel-Aziz Swelum, A.; Elsafadi, M.; Mahmood, A.; Osama, A.; Shikshaky, H.; Alfayez, M.; Alowaimer, A.N.; Magdeldin, S. Thermotolerance and plasticity of camel somatic cells exposed to acute and chronic heat stress. J. Adv. Res. 2020, 22, 105-118. [CrossRef]

17. Saadeldin, I.M.; Swelum, A.A.; Elsafadi, M.; Mahmood, A.; Alfayez, M.; Alowaimer, A.N. Differences between the tolerance of camel oocytes and cumulus cells to acute and chronic hyperthermia. J. Therm. Biol. 2018, 74, 47-54. [CrossRef]

18. Hansen, P.J. Physiological and cellular adaptations of zebu cattle to thermal stress. Anim. Reprod. Sci. 2004, 82-83, 349-360. [CrossRef]

19. Hassan, F.-u.; Nawaz, A.; Rehman, M.S.; Ali, M.A.; Dilshad, S.M.R.; Yang, C. Prospects of HSP70 as a genetic marker for thermo-tolerance and immuno-modulation in animals under climate change scenario. Anim. Nutr. 2019, 5, 340-350. [CrossRef]

20. Kerr, S.R.; Katz, S.G. Focus: Death: Activation of the Unfolded Protein Response Pathway in Cytotoxic T Cells: A Comparison Between in vitro Stimulation, Infection, and the Tumor Microenvironment. Yale J. Biol. Med. 2019, 92, 675-685.

21. Mayer, M.; Bukau, B. Hsp70 chaperones: Cellular functions and molecular mechanism. Cell. Mol. Life Sci. 2005, 62, 670. [CrossRef]

22. Schlesinger, M.J. Heat shock proteins. J. Biol. Chem. 1990, 265, 12111-12114.

23. Jindal, S. Heat shock proteins: Applications in health and disease. Trends Biotechnol. 1996, 14, 17-20. [CrossRef]

24. Saadeldin, I.M.; Swelum, A.A.; Tukur, H.A.; Alowaimer, A.N. Thermotolerance of camel (Camelus dromedarius) somatic cells affected by the cell type and the dissociation method. Environ. Sci. Pollut. Res. Int. 2019, 26, 29490-29496. [CrossRef] [PubMed]

25. Garrido, C.; Gurbuxani, S.; Ravagnan, L.; Kroemer, G. Heat shock proteins: Endogenous modulators of apoptotic cell death. Biochem. Biophys. Res. Commun. 2001, 286, 433-442. [CrossRef] [PubMed]

26. Urano, M. Kinetics of thermotolerance in normal and tumor tissues: A review. Cancer Res. 1986, 46, 474-482.

27. Ohtsuka, K. Thermotolerance in normal and tumor tissues. Gan no rinsho. Jpn. J. Cancer Clin. 1986, 32, 1671-1677.

28. Carper, S.W.; Duffy, J.J.; Gerner, E.W. Heat shock proteins in thermotolerance and other cellular processes. Cancer Res. 1987, 47, 5249-5255.

29. Van den Tempel, N.; Horsman, M.R.; Kanaar, R. Improving efficacy of hyperthermia in oncology by exploiting biological mechanisms. Int. J. Hyperthermia 2016, 32, 446-454. [CrossRef] 
30. Kosaka, M.; Othman, T.; Matsumoto, T.; Ohwatari, N. Heat Shock Proteins: Roles in Thermotolerance and as Molecular Targets for Cancer Therapy. Thermal Med. (Jap. J. Hyperthermic Oncol.) 1998, 14, 170-188. [CrossRef]

31. Dings, R.P.; Loren, M.L.; Zhang, Y.; Mikkelson, S.; Mayo, K.H.; Corry, P.; Griffin, R.J. Tumour thermotolerance, a physiological phenomenon involving vessel normalisation. Int. J. Hyperthermia 2011, 27, 42-52. [CrossRef]

32. Staples, J.F. Metabolic Flexibility: Hibernation, Torpor, and Estivation. Compr. Physiol. 2016, 6, 737-771. [CrossRef]

33. Geiser, F. Aestivation in Mammals and Birds. In Aestivation. Progress in Molecular and Subcellular Biology; Arturo Navas, C., Carvalho, J., Eds.; Springer: Berlin/Heidelberg, Germany, 2010; pp. 95-111. [CrossRef]

34. Saadeldin, I.M.; Swelum, A.A.-A.; Noreldin, A.E.; Tukur, H.A.; Abdelazim, A.M.; Abomughaid, M.M.; Alowaimer, A.N. Isolation and culture of skin-derived differentiated and stem-like cells obtained from the Arabian camel (Camelus dromedarius). Animals 2019, 9, 378. [CrossRef] [PubMed]

35. Song, A.S.; Najjar, A.M.; Diller, K.R. Thermally induced apoptosis, necrosis, and heat shock protein expression in three-dimensional culture. J. Biomech. Eng. 2014, 136. [CrossRef]

36. Gong, Y.N.; Crawford, J.C.; Heckmann, B.L.; Green, D.R. To the edge of cell death and back. FEBS J. 2018, 286, 430-440. [CrossRef] [PubMed]

37. Sun, G.; Guzman, E.; Balasanyan, V.; Conner, C.M.; Wong, K.; Zhou, H.R.; Kosik, K.S.; Montell, D.J. A molecular signature for anastasis, recovery from the brink of apoptotic cell death. J. Cell Biol. 2017, 216, 3355-3368. [CrossRef] [PubMed]

38. Tang, H.L.; Tang, H.M.; Mak, K.H.; Hu, S.; Wang, S.S.; Wong, K.M.; Wong, C.S.T.; Wu, H.Y.; Law, H.T.; Liu, K.; et al. Cell survival, DNA damage, and oncogenic transformation after a transient and reversible apoptotic response. Mol. Biol. Cell 2012, 23, 2240-2252. [CrossRef]

39. Tang, H.M.; Tang, H.L. Anastasis: Recovery from the brink of cell death. R. Soc. Open Sci. 2018, 5, 180442. [CrossRef]

40. Raj, A.T.; Kheur, S.; Bhonde, R.; Gupta, A.A.; Patil, V.R.; Kharat, A. Potential role of anastasis in cancer initiation and progression. Apoptosis 2019, 24, 383-384. [CrossRef]

41. Saadeldin, I.M.; Swelum, A.A.-A.; Elsafadi, M.; Moumen, A.F.; Alzahrani, F.A.; Mahmood, A.; Alfayez, M.; Alowaimer, A.N. Isolation and characterization of the trophectoderm from the Arabian camel (Camelus dromedarius). Placenta 2017, 57, 113-122. [CrossRef]

42. Petrie, A.; Watson, P. Statistics for Veterinary and Animal Science; John Wiley \& Sons: Hoboken, NJ, USA, 2013.

43. Hagai, T.; Chen, X.; Miragaia, R.J.; Rostom, R.; Gomes, T.; Kunowska, N.; Henriksson, J.; Park, J.-E.; Proserpio, V.; Donati, G.; et al. Gene expression variability across cells and species shapes innate immunity. Nature 2018, 563, 197-202. [CrossRef]

44. Li, L.; Wu, J.; Luo, M.; Sun, Y.; Wang, G. The effect of heat stress on gene expression, synthesis of steroids, and apoptosis in bovine granulosa cells. Cell Stress Chaperon. 2016, 21, 467-475. [CrossRef]

45. Luo, M.; Li, L.; Xiao, C.; Sun, Y.; Wang, G.-L. Heat stress impairs mice granulosa cell function by diminishing steroids production and inducing apoptosis. Mol. Cell Biochem. 2015, 412, 81-90. [CrossRef] [PubMed]

46. Aubrey, B.J.; Kelly, G.L.; Janic, A.; Herold, M.J.; Strasser, A. How does p53 induce apoptosis and how does this relate to p53-mediated tumour suppression? Cell Death Differ. 2017, 25, 104-113. [CrossRef] [PubMed]

47. Beere, H.M.; Wolf, B.B.; Cain, K.; Mosser, D.D.; Mahboubi, A.; Kuwana, T.; Tailor, P.; Morimoto, R.I.; Cohen, G.M.; Green, D.R. Heat-shock protein 70 inhibits apoptosis by preventing recruitment of procaspase-9 to the Apaf-1 apoptosome. Nat. Cell Biol. 2000, 2, 469-475. [CrossRef] [PubMed]

48. Hagn, F.; Lagleder, S.; Retzlaff, M.; Rohrberg, J.; Demmer, O.; Richter, K.; Buchner, J.; Kessler, H. Structural analysis of the interaction between Hsp90 and the tumor suppressor protein p53. Nat. Struct. Mol. Biol. 2011, 18, 1086-1093. [CrossRef] [PubMed]

49. Han, J.; Xu, X.; Qin, H.; Liu, A.; Fan, Z.; Kang, L.; Fu, J.; Liu, J.; Ye, Q. The molecular mechanism and potential role of heat shock-induced p53 protein accumulation. Mol. Cell Biochem. 2013, 378, 161-169. [CrossRef]

50. White, E. Autophagy and p53. Cold Spring Harb. Perspect. Med. 2016, 6, a026120. [CrossRef]

51. Highfield, D.P.; Holahan, E.V.; Holahan, P.K.; Dewey, W.C. Hyperthermic survival of Chinese hamster ovary cells as a function of cellular population density at the time of plating. Radiat. Res. 1984, 97, 139. [CrossRef]

52. Warters, R.L.; Henle, K.J. DNA degradation in chinese hamster ovary cells after exposure to hyperthermia. Cancer Res. 1982, 42, 4427-4432. 
53. Corver, W.E.; Cornelisse, C.J.; Hermans, J.; Fleuren, G.J. Limited loss of nine tumor-associated surface antigenic determinants after tryptic cell dissociation. Cytometry 1995, 19, 267-272. [CrossRef]

54. Danhier, P.; Copetti, T.; De Preter, G.; Leveque, P.; Feron, O.; Jordan, B.F.; Sonveaux, P.; Gallez, B. Influence of Cell Detachment on the Respiration Rate of Tumor and Endothelial Cells. PLoS ONE 2013, 8, e53324. [CrossRef]

55. Lin, C.; Tsai, S. The effect of cryopreservation on DNA damage, gene expression and protein abundance in vertebrate. Ital. J. Anim. Sci. 2016, 11, e21. [CrossRef]

56. Štětina, T.; Hůla, P.; Moos, M.; Šimek, P.; Šmilauer, P.; Koštál, V. Recovery from supercooling, freezing, and cryopreservation stress in larvae of the drosophilid fly, Chymomyza costata. Sci. Rep. 2018, 8. [CrossRef]

57. Jang, T.H.; Park, S.C.; Yang, J.H.; Kim, J.Y.; Seok, J.H.; Park, U.S.; Choi, C.W.; Lee, S.R.; Han, J. Cryopreservation and its clinical applications. Integr. Med. Res. 2017, 6, 12-18. [CrossRef] [PubMed]

(C) 2020 by the authors. Licensee MDPI, Basel, Switzerland. This article is an open access article distributed under the terms and conditions of the Creative Commons Attribution (CC BY) license (http://creativecommons.org/licenses/by/4.0/). 